IN THE RED CROSS WORLD

\title{
THE CENTENARY OF THE DANISH RED CROSS
}

The Centenary of the Danish Red Cross was recently marked in Copenhagen by a number of important ceremonies. This National Society is well known for its extensive and efficacious humanitarian activities both in Denmark and wherever there is conflict or catastrophe. On 1 May a solemn ceremony took place in the University auditorium. It was honoured by the presence of Queen Margrit, and was attended by many public figures including the Queen Mother, and Prince Henrik, who is head of the international relations division of the Danish Red Cross. The ICRC was represented by its President, Mr. Eric Martin, who was accompanied by the Delegate General for Europe, Mr. M. Borsinger. The League was represented by the Secretary-General, Mr. H. Beer; and the Finnish, Icelandic, Norwegian and Swedish Red Cross Societies were represented by their Presidents and General Secretaries.

After the Minister of the Interior, Mr. E. Jensen, had recalled the past achievements of the Danish Red Cross, Mr. E. Husfeldt described the present and future activities of the Society over which he presides. Other speakers were Mr. Lange, Rector of the University, and the Director of the National Bank, Mr. Andersen, who presented Mr. Husfeldt with a "national gift" of twelve million kroner, the product of the Centenary collection.

Earlier, Queen Ingrid the Queen Mother, patroness of the Danish Red Cross, had addressed the assembly, and we think it appropriate to give some passages from it because of the message of confidence which it contained:-

For many years, the Danish Red Cross has been called upon to fulfil important and large-scale missions. From being an organization whose sole function was to help the victims of war, it has widened its rôle to include assistance in important and varied tasks of a medico-social nature in our country. There is, for instance the training of nursing personnel and 


\section{IN THE RED CROSS WORLD}

of thousands of first-aid workers who contribute so much, in many sectors, to Danish society.

The Red Cross, founded by Henry Dunant, today represents an organization for humanitarian aid which all of us can support. I learned when $I$ was a little girl that the white flag bearing a red cross meant understanding for all in need, charity and a helping hand; in one word, help.

$I$ well remember that my father's uncle, Prince Charles of Sweden, who for many years directed the Swedish Red Cross, often discussed his problems with my father and mother. These problems concerned vital questions that the Red Cross tried to resolve during the First World War. $A$ little girl found it difficult to understand the nature of humanitarian aid, but I was conscious of the value of the help given to prisoners of war to whom the Red Cross parcels were sent; we, as children, knew that a parcel could save a human life. Millions of letters were exchanged between families separated by war. Thus the Red Cross widened its activities on the international level. Thanks to the experience thus acquired, the Red Cross was ready, during the Second World War, to play the role expected of it.

I think that the Danish Red Cross may be proud of what it has accomplished. Errors and omissions are inevitable, but one must take into account the immense difficulties encountered when it is necessary to organize aid as quickly as possible, often in places where what might be called normal conditions no longer exist, in time of war or in the case of a natural catastrophe. Gradually, we are going to perfect our work, to develop and to reinforce in the hearts of the people the confidence that they have in us. We live in a world of violence, a selfish world shorn of the spirit of understanding. But, in the cold climate of daily life, we do have an emblem of human brotherhood, a symbol that we may accept with gratitude: the Red Cross. Throughout the whole world it has shown that there are always idealists who devote themselves to the sick and the healthy, the young and the old. It is like a ray of sunshine penetrating the shadows.

\footnotetext{
'To the East the sun is rising Spreading gold accross the sky Accross the waves and mountain tops Across the country and the towns. It rises from that lovely side Where earthly paradise once was It brings us light and joy and life Whether we are great or small.'
} 
The ceremony was followed by a reception at the Royal Palace. Prince Henrik welcomed the guests, who included more than five hundred delegates from all the country's local branches. On the same day and the following day, they held their Annual General Meeting, during which Mr. Eric Martin conveyed the congratulations and warm wishes of the International Committee, which is united by numerous and ancient ties to the Danish Red Cross. He said, notably:-

It is always a great pleasure for the President of the ICRC to take the floor, as the representative of the founding organization of the Red Cross, to express his best wishes on the occasion of a great anniversary of a National Society. Today, however, that is more true than ever.

We cannot forget that it was in this country, in 1864, that a delegate of the ICRC, for the first time, helped the victims of an armed conflict. In fact, the International Committee was just one year old when one of its five founders, Dr. Louis Appia-wearing the first white armband bearing a red cross-undertook the co-ordination of the first international Red Cross operation during the Schleswig-Holstein War.

Already, on this occasion, the members of the Copenhagen Committee for aid to the wounded, precursors of those who would later found the Danish National Society, were active and had created an organization. Some twelve years later, on 27 April 1876, the present Danish Red Cross was recognized by the ICRC and from the beginning was very active in Denmark in times of both peace and war.

The ICRC remains profoundly grateful to the Danish Red Cross for its frequent and very generous help in bringing relief to victims of the First and Second World Wars, as well as during the conflicts which followed, in Asia, the Middle East, Africa, Europe and Latin America.

Not only did you give us very large sums of money for our aid activities but, thanks to you, Danish doctors and nurses served with our medical teams; they showed and still show a great spirit of self-sacrifice, often at the risk of their lives or, at the very least, their health. Your support for the activities of the International Committee is an admirable demonstration of the path that must in the future be followed by the Red Cross.

Finally, the Secretary-General of the League, as well as the representatives of the Nordic Societies who were also present at the Meeting, conveyed to the Danish Red Cross the best wishes of their respective institutions. 